\title{
Diplomatical Relations between the Emirate of Bukhara and Turkey
}

\author{
Shodiyeva Shahlo Saliyevna ${ }^{1}$, Ergashev Jahongir Yunus ugli ${ }^{2}$ \\ ${ }^{1}$ Bukhara state university, PhD research fellow of the chair of History of Bukhara \\ ${ }^{2}$ Bukhara State University, teacher of the dapartment of world history of History and cultural heritage faculty.
}

\begin{abstract}
The following article reconsiders the relations between the emirate of Bukhara and Ottoman Empire in the $19^{\text {th }}$ century also the exchange of ambassadors, includes the political cooperation which served to the bilateral relations of both countries. Also, there is an exchange of discourses on the exchange of correspondence between the emirs of Bukhara and the Sultans of the Ottoman empire.

Keywords: Ottoman empire, Turkey, Istanbul, Bukhara, Emirate of Bukhara, khanates of Central Asia, Mirza Muhammad Salimi, Boltaqulbek, Emir Nasrullakhan, Conolly, Stoddard, Emir Muzaffar, Sultan Abdualaziz, Khoja Muhammad Porso, ambassador, soldiers of Bukhara, weapons.
\end{abstract}

Article Received: 16th October, 2020; Article Revised: 30th December, 2020; Article Accepted: 08th January, 2021

Introduction. Based on the historical data, in the foreign policy of the Manghit dynasty, which ruled in the Emirate of Bukhara, diplomatical relations along with economic relations, political relations were significantly intensified towards some Eastern countries. These aspects are especially evident in relations with neighboring Turkey and Iran. The increase in Ottomani attention to the Uzbek khanates was mainly due to the war between Russia and Turkey in 1768 and the Kuchuk-Kaynarja peace treaty signed in 1774 [6.-P.202]. This truce marked the beginning of a period of crisis in the Ottoman Empire and ended in 1783 with the official declaration of Crimea's subjugation to Russia [9.-P.60].

Of course, the Russian occupation of Crimea, which was of great strategic importance, was a great loss for the Ottoman Empire. Because Russia, which occupied Crimea, was threatening the Ottomans from the Caucasus. In this situation, the Ottomans were initially forced to look for allies in European countries [9.-P.71]. The Ottomans signed a treaty of friendship with France in 1801 to reclaim Crimea from Russia with the help of the French [4.-P.80], but when they failed to achieve the expected result, they began to strengthen allied relations with the Uzbek khanates to achieve their goals. The emirs of Bukhara, in their turn, used the sultan's reputation as the most powerful Muslim ruler to seek financial protection from the Ottoman Empire for military equipment and military affairs when they appealed to him to protect the Muslims of Central Asia. They maintained constant diplomatic relations with the Ottoman Empire throughout the $19^{\text {th }}$ century by periodically sending ambassadors to Istanbul. And the ambassadors constantly informed the Sultan's Palace with information about the situation in the Central Asian region.

Main part. The Bukharian diaspora in Istanbul had a special place in this system of bilateral relations. Emir's representatives were invited to the sultan's palace for political advice and sent to Bukhara on a secret diplomatic mission. It should be noted that the local rulers, relying on the help of the sultan, also intended to strengthen their position or to resolve the situation in their favor in local civil wars[2.-P.20-21]. Also, according to historical facts, they appealed to the sultan to send weapons, teachers, and experts in various fields of industry. 
Diplomatic relations of the Emirate of Bukhara with the Ottoman-Turkish state were more active during the reign of Daniyalbiy otaliq(1758-1784). This connection was continued during the reigns of the next representatives of the Manghit dynasty, Emir Shahmurad and Emir Haydar[17.-P.20]. The Emir of Bukhara, Shahmurad, sought to resolve the strained situation in Bukhara's political relations with Iran with the help of Turkey and Russia.

According to historical sources, the diplomatic correspondence of the Emirs of Bukhara with Ottoman Empire consisted of references, which were written asking to establish trade relations between the two countries, to take concrete measures to ensure security on the roads of trade caravans[1.-P.136].

The Emir's correspondence with the Ottoman Sultan clearly indicated that the desire for peace and harmony in relations between the two countries, the development of long-standing trade, the desire to strengthen interests between the two countries and the removal of obstacles were common goals. Because at a time when relations with its close neighbors were strained, the expansion of ties with the Ottomans was one of the important tasks of the Emir's diplomacy.

Although the Ottoman government was reluctant to issue a fatwa on Bukhara's supremacy over the Central Asian khanates, and the Bukhara emirs did not support the Ottoman attitude towards Iran, embassy relations between the Ottomans and the emirate did not interrupt. In particular, the document written by the Ambassador of Bukhara Mirzo Muhammad Fazil, addressed to the Sultan of the Ottoman Empire, confirming the delivery of the letter of the Emir of Bukhara [5.-P.20] is a proof of our opinion. The letter states that the conspiracies that took place in the Bukhara Emirate over the past five years and the severance of ties between the Ottoman Empire and the Bukhara Emirate due to the uprisings in Tashkent, Kokand, Khorezm, and Dashti Kipchak, it was reported that it was only after the struggle against these rebellions and conspiracies, their suppression, and the establishment of peace that it was possible to re-establish relations with the Ottoman Empire, on behalf of the ruler of Bukhara, he expressed his loyalty and friendship to the Ottoman sultan through prayers and greetings, stating that the main goal of mutual friendly cooperation [5.-P.22-23]. These diplomatic relations continued during the reigns of the ruler of Bukhara Emir Nasrullakhan (1826-1860) and Emir Muzaffariddinkhan(1860-1885). For example, according to the tradition that each new khan should send ambassadors to some countries and inform the rulers of those countries, Amir Nasrullakhan also sent Boltaqulbek Chigataybegi, one of the forty clans, to the Ottoman sultan Abdulmajid to inform the Ottomans about his accession to the throne. Boltaqulbek Chigataybegi traveled to Istanbul via Iran and, according to custom, stopped to pay homage to the ruler of this country (although Kabulbek was sent as an envoy to Iran). This information was written by Mirza Muhammad Salimi, the author of "Kashkuli Salimi" or "Tarihi Salimi". It is written that Boltaqulbek Chigataybegi, who was of forty clans, was a very enterprising, intelligent, wise and eloquent diplomat. He wisely responded to the words of Shah Muhammadshah Qajar of Iran, "The people of Bukhara kidnap and sell the citizens of Iran and make a living and they send ambassadors to the kings without shame" and was able to escape the situation and gain the king's attention. In particular, he replied to the king of Iran when he stood before the king in accordance with the rules of this state: “... It is known to Shakhanshakh that from ancient times the Rulers of Bukhara were famous and known in most countries. Some people doubt and disbelieve this. There is a Turkmen community between the state of Bukhara and the state of Iran, 
which they do not follow the laws of Bukhara or Iran. They have chosen the path of tyranny and plunder. They kidnap, capture and sell Iranian citizens in Bukhara markets. The people of Bukhara buy the captives and help them with the help of the nobility and compassion and release them. They (captives of Iran) took Bukhara as their homeland, made it their home, became rich, even held high positions in the service of kings, and made the province of Iran out of their memory" [8.P.59a]. Muhammadshah was pleased to hear these words and said to Boltaqulbek: Saying "Apart from good deeds, you have made me happy and calm with your answer", presented money, special attire, and his riding horse Kabood (Blue) [8.P.59b]. The king of Iran held a banquet in honor of the ambassador of Bukhara for a few days and then ordered his officials to escort him to the Turkish border[7.-P.112]. After the successful visit of Boltaqulbek Chigataybegi Rahmatbek oglu to Iran, he and his companions arrived in Istanbul, the capital of the Turkish Sultanate.

Prior to be received Sultan Abdulmajid according to the customs he was accepted and hosted in the house of the qaplanbashi (we assume that he was the representative clerk dealing with the foreign affaires of Turkish sultan Sh.Sh)and asks the ambassador to present the letter of the emir named to the sultan in order to present it to sultan.

However, the ambassador of Bukhara, Boltaqulbek Chigataybegi, said that he would personally hand over the title to the sultan on the orders of his ruler [8.-P.59b]. A few days later, the qaplanbashi escorted the ambassador to the Sultan. According to the Bukhara tradition, Ambassador Boltaqulbek tied a futa (horn belt) around his waist and fastened a dagger in the middle. Despite the qaplanbashi's objections to the ambassador, explaining that the custom was not in accordance with the Sultan's nature, the ambassador said that he would strictly adhere to his tradition and would be able to enter the presence of Sultan Abdulmajid. In his work, Mirza Salim describes the ambassador's visit to the Sultan as follows and writes: "Sultan Abdulmajid saw the belt and dagger in the ambassador and asked him the reason for this. The ambassador stood in front of the Sultan and replied: "Rulers from ancient times honored their servants to the rank of emirate and gave them a sign. For example, in Istanbul the symbol of the emirate is called Pasha, in India and Iran Khan, in Bukhara - Bek. This belt and the dagger are signs of that" [8.-P.60]. By this act, the ambassador not only showed that he was a high-ranking official in the government of Bukhara, but also gained the respect of the Sultan and achieved diplomatic success.

The Turkish sultan, Abdulmajid, was pleased with the ambassador's response and placed on his chest the highest order of the sultanate, "Majidiya" (Salvation) badge and says: "... today you have received two marks of kings" [8.-P.60]. Ambassador Boltaqulbek returned to Bukhara after 6 months in Istanbul.

During the reign of Amir Nasrullakhan, ambassadors came not only from Bukhara to Istanbul, but also from Istanbul to Bukhara. In particular, the British officer A. Connolly, who was sent to Khiva, Kokand and Bukhara in 1840 by the British government to create a union of Central Asian khanates against the Russian invasion in cooperation with Turkey, as well as the need to release M. Stoddart, their detention was not in accordance with international law, wrote two letters and sent them to the Emir of Bukhara through ambassadors [3.-P.250-254]. But despite this letter, Emir Nasrullakhan executed Conolly and the Stoddart.

Although the expected results were not achieved, the embassy relations of the Emirate of Bukhara with Turkey continued during the reign of Emir Muzaffarkhan (1860-1885). For example, when the Governor-General of Turkestan Chernyaev started an undeclared war to subdue the 
Emirate of Bukhara in January 1866, Emir Muzaffarkhan sent the Mufti of Bukhara Khoja Muhammad Porso (Khoja Muhammad Porso was one of the most famous people of his time. Porso was educated by his father. During the reign of Emir Muzaffar, he was in the career of Mufti askariya. In the last years of his life he was on diplomatic missions in Turkey and India. He lived in India for some time and then died in Bombay.) as an ambassador to Istanbul, seeking protection and assistance from the Russian occupation[12.-P.63]. Hodja Muhammad Porso came to Istanbul via Afghanistan and India. The ambassador also cited letters from the Emir asking for help on behalf of Johnny Lawrence, the British representative to India, and the Queen of England. However, not forgetting that in 1842 the Emir of Bukhara executed British officers Ch.Stoddart and A.Connolly, the British government refused, referring to the long distance between Bukhara and wished the Emir success in the fight against the invaders[16.-P.75].

After a negative response from the British, the depressed ambassador set out and in September 1867 entered the Ottoman capital. He was very well received by the Ottoman Mufti in Istanbul. On September 24 , a ceremony was held to receive the sultan's ambassador. Khoja Muhammad Porso informs the sultan of the situation in Turkestan, of the Russian attack, and delivered the first letter of the emir and the gifts he had given. Emir Muzaffar's letter to the Ottoman sultan, which is now in the Manuscripts Archive of the Institute of Oriental Studies of the Academy of Sciences of Uzbekistan, states that the caliph (Sultan of Turkey. At that time, the Sultan of Turkey was the caliph of the entire Muslim world. Sh.Sh.) traditionally wanted to send a special letter stating that he had ascended the throne of Bukhara, but the internal and external political situation in the country. The uprisings of the principalities were prevented by the
Russians from invading the territories of Turkestan[13.-P.64].

The Emir's letter states that the DashtiKipchak lands, which were the borders of the Kazakh people, were occupied by the Russians 20 years ago (1846), where the Russians settled in the fortress of the White Mosque, fortified it, and then continued their policy of invasion and entered the Kokand Khanate and that they had recently formed a province in the territories they had conquered.

Muzaffarkhan also wrote that the people of Tashkent had appealed to Bukhara for help, and that the Emir had sent an ambassador to the Russians to find out the real situation. According to the letter, the Russians captured the ambassadors of Bukhara, crossed the Syrdarya and began the siege of Jizzakh region. However, they were unable to conquer the land and returned to the Syrdarya River. It was in this situation that the Emir declared jihad and decided to attack and wage a fierce battle against the Russian invaders on the banks of the Syrdarya. According to Muzaffarkhan, the Bukhara warriors had never encountered an enemy with such powerful weapons and artillery as the Russian military, and had no idea about European weapons. Due to the lack of modern tactics of warfare, the lack of centralized management and command, the backwardness of the supply of weapons, the Bukhara army was defeated in this battle [13.-P.65b]. The letter says that about the conquest of the Khujand by the Russians: "The Muslims are preoccupied with fortifying the city (Khujand-Sh.Sh.) and leaving its river side unprotected, as a result of which the Russians take advantage of the situation, placing cannons in boats, crossing the river by boat and the battle begins. In the battle, great clerics, sayyids, eshans and other defenders of Islam were killed"[13. P.66b].

At the end of the letter, words from the Holy Quran are quoted, reminding the Greek caliph (Sultan of Turkey - Sh.Sh.) of 
the need to protect the rights of Muslims, and asking for help in the fight against the Russians [13.-P.67a]. Finally, Muzaffarkhan mentions the name of his ambassador, Muhammad Porso Khoja Sadr, and reminds him that he could convey some of the unfinished words in the letter through the words of the ambassador [13.-P.67b].

According to the decree of the Sultan, the ambassador Khoja Mohammad Porso, who handed over the letter, 50.000 Qurush money was allocated for the expenses of going to the Haj. The ambassador's written request to the British ambassador to Istanbul, Henry Elliott, for help in the Emirate of Bukhara, dated November 24, 1867, also ended in failure. In a reply letter, the British government considered the response written by its representative in India, John Lawrence, to be sufficient, stating that it had not yet forgotten the tragedy of Stoddart and Connolly.

Emir Muzaffarkhan von Kaufmann, who could not keep up with the Russians in terms of modern military weapons, sent an envoy and offered to sign a truce agreement [11.-P.216-218]. However, the agreement was not signed after Kaufman set very strict conditions for the Emir of Bukhara. Emir Muzaffarkhan used one of his last chances to send ambassadors to the Ottoman sultan and asked for urgent help. Two letters, one from Emir Muzaffarkhan and the other from Muhammad Shah, written about the recent events in Turkestan, were received by Ambassador Muhammad Porso, who had returned to Istanbul from Mecca in April 1868 on a pilgrimage. He handed over to the Ottoman government a letter written by Emir Muzaffarkhan in Persian on February 7, 1868, signed by a total of 14 people, including courtiers and clerics [14.-P.102]. This letter was written by Mulla Wahid Sadr on a piece of paper in a nastaliq letter by the order of Amir Muzaffarkhan. Emir Muzaffarkhan's address to the Ottoman Sultan Abdulaziz included the following lines: "We would like to complain to you for the last time that Russia's occupation activities have increased its courage. Leaving the White Mosque, which the Russians had been using as a stronghold for some time, they captured Hazrat Sultan, Shymkent, Avliyota, Khujand, and Tashkent, martyred many of the people, and inflicted extreme injustice and oppression on the Muslims. While living in Yangikurgan, the governor of Orenburg (Krjijanovsky meant) sent us a letter expressing his desire to make peace. As a result, we were deceived by him and sent the army back. When the disbelievers heard this, they did not take their army from Yangikurgan. We expressed the development of the event. Let the Caliph keep the Russians away from the Muslims, so that Islam may flourish and not weaken. On this side, His Majesty has built an artillery, and a 10,000-strong army is confronted by the infidels. If the Caliph sends a letter or a person to distance the Russians from the Muslims, it will be a reason for the development of the state and its good remembrance. If the helpless Muslims are saved by this grace of the Caliph, a great reward will be written in the book of deedsLet the Caliph be informed of the plight of the helpless and helpless Muslims" [14.-P.102]. The sultan ordered that the letter be examined in a "Special majlis".

The letter of Muhammadshah, a kushbegi of Bukhara, was written in the same context. While writing about the situation, Kushbegi asked the ministers and the chairman of the Ottoman palace to explain the situation in Bukhara to the sultan. But the Ottoman sultan Abdulaziz was not in a position to help the Emir of Bukhara. While the Ottoman government was discussing the letter of the Emir of Bukhara in the a "Special majlis", the Russians continued their military operations in Turkestan. In response, the Ottoman state called on Bukhara not to confuse relations with Russia[10.-P.4].

At that time, the situation in the Balkans was complicated. The Ottoman empure 
which was recognized as the European country in 1856 was ruling over 12 million Slavs, Greeks and Albanians in the territory of Balkan Peninsula [9.-P.93]. At the same time, the peoples of the Balkans were fighting for their independence. In the second half of the $19^{\text {th }}$ century, protests in the Balkans rose from time to time. Russia's growing influence in the Balkans posed a threat to Turkey. That's why because of his visit to the big exhibition in the Paris based on the invitation by the French emperor Napoleon III in France in 1867, while returning back meeting with the Queen of England Victory, King Leopold II of Belgium, King of Prussia Wilhelm I, Emperor of Austria and King of Hungary Franz Joseph I, Prince of Romania Charles I the Sultan Abdulaziz at last expressed his will to discuss the letter of the emir of Bukhara.

The last appeal of the Emir of Bukhara for help was considered in May 1868 in the "Special Majlis". In the meantime, however, news reached Istanbul that a war had broken out between Bukhara and Russia and that the defeated Emir Muzaffarkhan had been forced to make peace with the Russians. Upon learning of this, Khoja Muhammad Porso asked that instead of the weapons previously requested, he be given a specialist to teach war tactics, artillery and ball-adjusting masters, and that he be allowed to send Sheikh Suleiman efendi, who would explain Ottoman rule to the people of Bukhara. This request of Mulla Muhammad Porso will also be considered in the "Special Majlis". On February 20, 1869 , the following resolution of the meeting was announced:

"Earlier, too, the emirate of Bukhara had asked Russia for help from us to protect themselves. But we recommended to improve relations with Kokand and Khiva for the distance between us. After the Russian invasion and losing Tashkent the ambassador was sent. We offered them our own offer, that is, to have a good relationship with Russia. The situation between Russia and Britain in the international arena can put us in a difficult position. The situation in Bukhara is becoming more complicated.

After the truce between Russia and Emir Muzaffarkhan, Khoja Muhammad Porso announced that he would return to his country, and he asked a tactical teacher, ball and ball-adjusting masters not to return without anything. But we can't accept that. The reason is that the Russians may protest. We hope to provide this assistance later. We decided to send Sheikh Suleiman and the ambassador to Bukhara and allocate 75,000 qurush (money) for travel expenses. By the decree of our king, the above will be answered" [16.-P.100]. The Ottoman Sultan Abdulaziz liked the above conclusion of the "Special Majlis". In 1868, Khoja Muhammad Porso and Sheikh Suleiman set out from Istanbul for Bukhara (According to some authors, Suleiman effendi was sent by the Turkish sultan as a spy in agreement with the British. Sh.Sh.) [15.-P.34]. When Sheikh Suleiman arrived in Bukhara, he handed over a letter from the sultan informing him of the situation in the Ottoman state and the impossibility of providing military assistance to Bukhara. The letter stated that the Ottoman state's desire to help was hampered by the presence of several states in the meantime. The Ottoman government said it was pleased with the ambassadors sent by the Emirate of Bukhara and was sending its own ambassadors as proof.

Afterwards the Emir Muzaffarkhan had never stopped hoping for the assistance by the Turkish Sultan, even though Turkish Sultan hadn't assisted in the critical moments needed by Bukhara.

Conclusion. In short, from the end of the 18th century until the conquest of Central Asia by Tsarist Russia, embassy relations between the Emirate of Bukhara and the Ottoman Empire were mainly political The Emirate of Bukhara initially sent an ambassador to Turkey in the anticipation of an alliance with the Ottoman government in order to liberate its 
territories: Merv, Karki, Balkh, and the southern provinces from Iranian political influence, and to capture Mashhad, the political center of Iran in the north, he continued his embassy contacts in order to obtain a fatwa affirming his superiority among the Central Asian khanates, and to seek support from the Islamic caliph against the invaders of Tsarist Russia. In turn, the Turkish sultans also had a political goal of establishing embassy relations with the Emirate of Bukhara, which, together with Britain, sought to form an alliance of Central Asian states

\section{REFERENCES}

1.Valieva D. Buxoro - Eron aloqalari tarixiga doir // Sharqshunoslik. №8. -S.133-143. Valieva D. XIX asrning birinchi choragida BuxoroRossiya diplomatiya aloqalariga doir //Sharqshunoslik. - 1999. -№9. P.120-122.

2.Vasilev A.D. Vzaimootnosheniya Osmanskoy imperii i gosudarstv Sentral noy Azii v seredine XIX nachale XX vv. Avtoreferat na soisk. uchen. step. kand. ist. nauk. - M.: 2007. -P.28.

3.Vasilev A.D. Turetskiy sultan i plenniye anglichane $\mathrm{v}$ Bukhare. Osmanskiy dokument iz perepiski ob osvobojdenii arestovannix v Bukhare britanskikh agentov Charlza Stoddarta i Artura Konolli//istoricheskiy vstnik' rossiya i islamskiy mir. T. pod obshey redaktsiey d.r. Jantieva - M.: 2015. P.250-256.

4.Vneshniye ekonomicheskiye svyazi Osmanskoy imperii v novoe vremya (v kontse XVIII-XIX vv.).M.,1989. P.80.

5.Istoriya Tsentralnoy Azii $\mathrm{v}$ osmanskix dokumentax. Tom III. Obshestvennaya

ipovsednevnaya jizn`. Samarkand: MITSAI, TOA. 2012. -P.313. against Tsarist Russia. However, the policy of the Emirate of Bukhara towards Iran and neighboring khanates was not supported by the Turkish sultans, the aid he asked for to wage war against Russia was not provided by the Sultan. At the same time, the Turkish sultan was unable to resolve the internal disputes between the Central Asian khanates and failed to form an alliance between them against Tsarist Russia. Due to this, the period of stagnation in Bukhara-Ottoman relations began.

6.Miller A. F. Mustafa pasha Bayraktar [Tekst] : ottomanskaya imperiya $\mathrm{v}$ nachale XIX veka / A. F. Miller. M.; L.: Izd-vo AN SSSR, 1947. P.507.

7. Mannonov B. O'rta Osiyo va Eron elchilik munosabatlari tarixidan // Eron. Maqolalar to'plami. Toshkent: Fan, 1977. - P.112.

8. Mirza Muhammad Salim. Tarixi Kashkuli Salimiy // O'zR FA SHI. Inv.- №2016, V.59a-59 b-P.60.

9. Novichev A. D. Turtsiya [Tekst]: kratkaya istoriya / A. D. Novichev ; Leningr. gos. un-t im. A. A. Jdanova. - Moskva: Nauka, 1965. -P.269. Bartold V.V. Istoriya kulturnoy jizni Turkestana. Soch. v 9-tomax. Tom II. chast 1. - M.: Nauka , 1963. P.1016.

10. Pokrovskiy S. Mejdunarodnie otnosheniya Rossii i Buxari v dorevolyutsionnoe vremya // Byulleten SAGU. - Vip.16. Tashkent, 1927.- P.4-9.

11.Popov A.A. Iz istorii zavoevaniya Sredney Azii //Istoricheskie zapiski. - 1940. - №9. - P.216-218.

12.Tarixi Rokimi O'zR FA SHI, Qo'lyozmalar xazinasi, Inv.№3282. V.63; Nizomutdinov. XVI-XX asrlarda O'rta Osiyoning Rossiya bilan tarixiy va iqtisodiy aloqalari. Toshkent: Fan, 1965. - P.22.

13.O'zR FASHI, Qo'lyozmalar xazinasi, Inv.№ 2882-IV.-V. -P.64. 
14. O'zbekistonning yangi tarixi. Turkiston chor Rossiyasi mustamlakachiligi davrida. -Birinchi kitob. -T.: Sharq, 2000. -P. 464.

15.Xalfin N. Sultanskaya Turtsiya i Angliyskaya ekspansiya v Sredney Azii (50-80 gg. XIX v.) // Trudi SAGU. - Vip.XXCV. - Kn.14. Tashkent: SAGU, 1957. - P.37-41.

16.Mert O. Buhara emirligi elcisi Muhammed Parsa Efendinin Istanbuldaki diplomatik faaliyeti (1867-1869). - Ankara.: Turk Kulturu Arastirmalari XV. 1/2 1976. - P.100

17.Saray M. Rus isgali devrinde Osmanli devleti ile Turkistan hanliklari arasindaki siyasi munasebetler (1775-1875). - Ankara., 1994. P.114.

18. Ergashev Jakhongir Yunus ugli. On problem of the composition of Bukhara market and volume of trade in late medieval period.International Journal of Psychosocial Rehabilitation.- Volume 24, Issue 3, UK, 2020. - P. 325-330. (Scopus journal)

19. Ergashev Jahongir Yunus ugli. Development of transportation types and their usage on caravan roads in middle ages. - International Journal on Integrated Education journal. Volume 3, Issue II, Feb 2020. - P. 19-23 (impact factor - 5.06)

20. Ergashev Jahongir Yunus ugli Transportation means on the caravan roads of the late middle ages // International Scientific Journal "History Research Journal", 5(5), P.10-19. Impact factor search 5.3 \# 39. 